
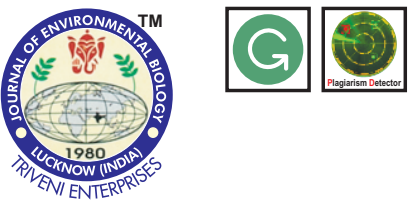

DOI : http://doi.org/10.22438/jeb/38/5(SI)/GM-20

\section{Journal of Environmental Biology}

ISSN: 0254-8704 (Print) ISSN: 2394-0379 (Online) CODEN: JEBIDP

\title{
Mapping of biotopes between Amasra and İnkum (Bartın), Western Black Sea Region of Turkey
}

\section{Authors Info}

\section{Y.S. Nayim*}

Department of Landscape Architecture, Faculty of Forestry, Bartın University, Bartın, 74100, Turkey

*Corresponding Author Email : yelizsari@yahoo.com

Key words Amasra-Inkum (Bartın), Black Sea Region, Ecological and floristic diversity, Mapping biotopes

\section{Publication Info}

Paper received : 30.07 .2016

Revised received : 25.06 .2017

Accepted : 27.06.2017

\section{Abstract}

Aim: The aim of the study was to identify and map the biotope areas located between Amasra and İnum settlements of Bartın Province, an important coastal province in the northwest of Black Sea Region in Turkey. This region represents the onshore Euxin part of Euro-Siberian phytogeographical province. Flora, abiotic characteristics, actual vegetation and land uses were taken into account for identification of biotopes found in the research area, which has a rich ecological and floristic diversity.

Methodology: Remote sensing and GIS were effectively used for preparation and interpretation of data, and necessary satellite images, digital maps and databases for analysis were also generated. Composition of species belonging to plant cover was used as an indicator in addition to other factors for distinguishing different biotopes. Vegetation surveys were carried out and inventories were made in selected 156 sample plots that represent various ecological and floristic characteristics.

Results: Eleven main biotopes were identified viz., deciduous forest lands, afforestation areas, agricultural lands, shrublands, cliffs, İnkum Dune area, Bartın Riverside, roadsides, degraded lands, urban settlements and rural settlements. These biotopes may be divided into 30 sub-biotopes. In other words, a total number of 41 biotopes were classified and mapped during the research.

Interpretation: With the mapping of the biotopes covering species that have a special importance in the area, a base has been achieved to manage the formation of aims and the conservation status of the ecosystems special to the Black Sea at landscape level.

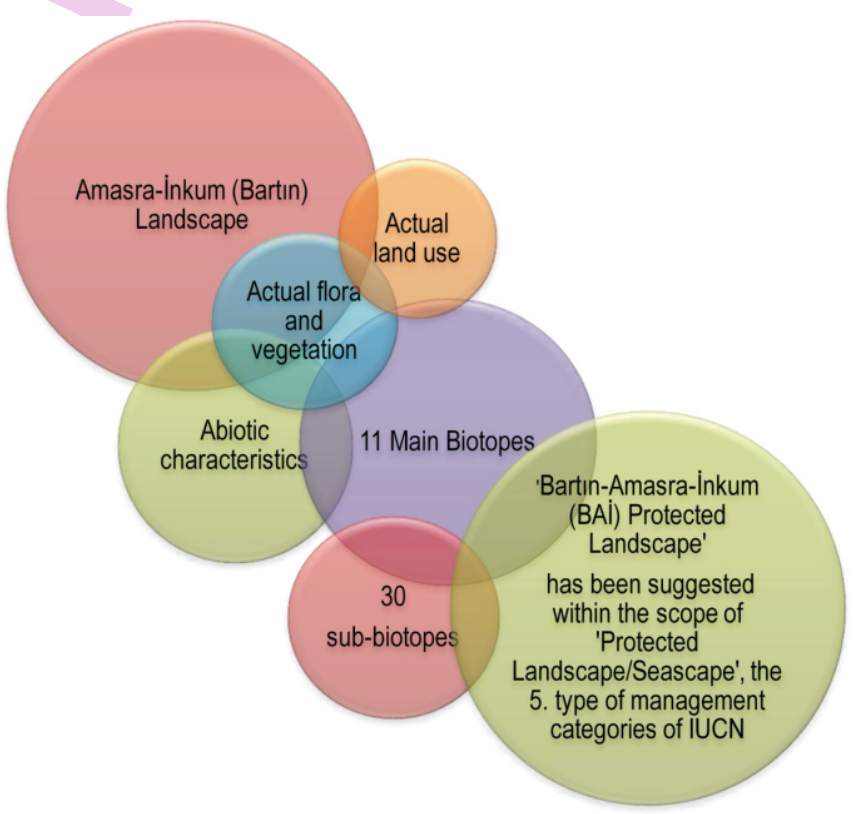




\section{Introduction}

When the ecological research based on field studies that started in Central Europe in 1960s and developed in the following years are examined, it is seen that system analysis studies focus on identifying landscape elements in a complex system (Forman and Godron, 1986). In order to understand the structure and function of all ecological systems covering continental, nautical, water-based and cultural systems, the current study focuses on the analysis of landscape elements within the whole ecosystem using ecological principles (Odum and Barrett, 2005). The term 'biotope' used as a main element in landscape ecology studies is accepted as the smallest unit representing a whole (Ayaşlıgil, 1987; Ayaşlıgil and Duhme, 1993). This concept, which is closely related to organism, species, population and community, which are at the lowest level of ecology's occupation, was defined by Dahl (1908) as 'An area of uniformity in climate and distribution of biotic and abiotic components' (Ayaşlıgil, 1987; Ayaşlıgil and Duhme, 1993).

Researching, defining, classifying and mapping these smallest homogenous units that form the basis of modern landscape ecology are important sources of data for analysis, evaluation and planning of landscape (Bastian and Steinhardt, 2002). Landscape ecology studies, which consider the spatial organization of biotopes, the structures and processes perceived via different species, form a scientific basis for planning, design, management, protection and cultural area management; and provide the required data for natural and cultural area management at regional scale (Hersperger, 1994; Farina, 2000; Odum and Barrett, 2005). Therefore, mapping ecologically important biotopes reveals delicate ecosystems necessary for nature conservation; and with protected area method, it is possible to develop, manage and sustain ecological infrastructure (Forman, 1995).

The earth offers a richness of species and habitats for biomes at the highest level and biotopes at the lowest level. However, today, the human impact has started to affect all biotopes, landscapes, biomes and ecosphere negatively and even started to threaten the existence of living things (Curebal et al., 2015). As of 1970s, this negative process forced countries around the world, particularly the European countries, to take a series of precautionary measures to protect nature (Odum and Barrett, 2005; Ayaşlıgil, 1987; Ayaşlıgil and Duhme, 1993; Sarı Nayim, 2010).

Biotope mapping studies which were first carried out by Prof. Dr. Haber and his colleagues in 1970s at Landscape Ecology Chair at Munich Technical University in Germany, formed the base of nature conservation practices (Ayaşlıgil, 1987; Ayaşlıgil and Duhme, 1993). In this process, biotope maps were used as indispensable parts of landscape planning studies particularly in Germany. The most important reason behind it is that these maps provide reliable, holistic and all-round useful information on species and their habitats, distribution of landscape elements and their quality (Werner, 2006). Biotope mapping, which first undertaken and practiced in rural areas widely, later started to be studied and practiced in urban areas, again first in Germany (Ayaşlıgil, 1997). Berlin, Munich and Augsburg were the first cities where urban ecological research started (Environmental Atlas, 2009). Methods used for identifying urban biotopes are grouped into three, namely, selective mapping, representative mapping and comprehensive mapping. These methods are also used in identifying rural biotopes.

Increasing pressure on ecosystem makes it necessary to create an environmental database in the European Union. This necessity resulted in CORINE (Coordination of Information on the Environment) Programme between 1985-1990 (European Communities, 1991). After the first program, many other ecological network systems such as CORINE Land Cover Classification, CORINE Biotope Project, Natura 2000 Network System, Habitat Directives and Policies, EUNIS Biotope Classification and Information System and various databases and classifications were formed (European Commission, 2003; Oudheusden, 2005; EUNIS, 2005).

In CORINE Habitat Classification, the main themes of the methods used in biotope mapping are illustrated clearly. In this classification, important distinguishable communities resulting from the interactions between flora, fauna and abiotic environmental factors are identified (Oudheusden, 2005). Natura 2000 and EUNIS habitat classifications, on the other hand, are formed according to the CORINE Biotope typology (Devillers et al., 1991; Oudheusden, 2005; Guth and Kucera, 2005). The classifications are based on vegetation analysis and this system is very old and important in European history (European Communities, 1991). In biotope mapping studies by Cousins and Ihse (1998) in Sweden rural landscape, by Münier et al. (2001) in Denmark, by Löfvenhaft et al. (2002) in Stockholm, by Guth and Kucera (2005) and Chrtry et al. (2001) in Czech Republic, by Jarvis and Young (2005) and Zerbe et al. (2003) in the United Kingdom distribution of plant communities, abiotic features and different area utilizations were considered to be in constant interaction; and satellite images and aerial photographs were used as the most efficient and reliable materials in identifying, mapping and monitoring biotopes (Sarı Nayim, 2010). While classifying semi-natural vegetation and wildlife habitats, the UK uses a standard field survey technique. This technique includes releve studies based on phytosociological roots. These studies that include the classification and definition of semi-natural plant communities are basically carried out via floristic information that is correct and recorded in detail (JNCC, 2014). Studies revealed that plant cover is an important parameter in biotope mapping.

Whilst biotope mapping, which enables rational utilization of natural resources and their protection, has a significant place in 
studies towards protecting nature and landscape planning in developed countries, it is a new area of research in Turkey, which is in the European Union accession process (Ministry of Environment and Forestry, 2007; 2010). In fact, Turkey is within a very wide transition zone in between Euro-Siberian, Mediterranean and Irano-Turanian phytogeogrophical regions (Atalay and Efe, 2015; Efe, 2010). Whilst the European continent has 12,500 plant species, Turkey, alone has almost 11,000 plant species, of which $1 / 3$ are endemic (Ministry of Environment and Forestry, 2007). With a wide range of plant species, Turkey incorporates a diverse ecosystem and species diversity that could significantly contribute to European Habitat types. Considering the richness of species and biotopes in the country, it is seen that studies carried out in our country until present day are not enough and that more in-depth studies are required (Sarı Nayim, 2010).

It is also illustrated in United Nation's Report that Turkey made limited progress on Natura 2000 Habitat Directives, therefore, it is necessary for Turkey, in the process of harmonization to EU, to make in-depth research on the classification of the habitat types it has (Ministry of Environment and Forestry, 2010; Sarı Nayim, 2010).

With its almost natural forests and pseudomaquis communities, cliffs, dune areas, riverbeds and riversides, rural and urban biotopes, the Black Sea Region, where the research area is located, is an important area for EU Natura 2000 habitats. These areas, which have not received deserved importance, because they were not known and where more research should be carried out, are rich in species and biotope diversity. According to European Commission (2009) report, during last 50 years there have been many changes in area utilization that pose a threat to species and biotope diversity in the Black Sea Region, and this is still ongoing today. The Black Sea coastal areas are intensely used for agricultural and industrial activities, energy generation, mining works, shipping, cruises, urban development and tourism. Despite all these threats, Black Sea Region still offers an important shelter to natural plant and wild life.

This plant and wildlife potential once again reveals the necessity of defining and mapping important biotopes in the region in connection with international habitat systems. In view of the above the present study aimed the following

To identify and map ecologically and biologically important biotopes in Amasra-Inkum settlement areas, which represent the onshore Euxin part of Euro-Siberian phytogeographical region in Western Black Sea Region in Turkey; to identify the negative factors effecting the species and biotopes in the region; to evaluate the international significance of the defined biotopes; to offer suggestions for the protection, maintenance and development of species and biotopes at landscape level.

\section{Materials and Methods}

In determining and classifying the biotopes in the research area, the flora, abiotic structure, actual vegetation structure and differences in land uses were taken into account. In this method which was followed to classify biotopes in the rural area, biotope classification models particularly 'Representative Mapping' method of Sukopp and Weiler (1988) as well as CORINE Biotope Project (European Communities, 1991), Natura 2000, EUNIS (Davies et al., 2004) and Guth and Kucera's (2005) biotope classification were used. In biotope mapping in urban areas, Sukopp and Weiler's (1988) 'Comprehensive Mapping' and 'Representative Mapping' methods were used by considering Yılmaz's (2001) study as well.

Collection of data in biotope mapping method was carried out in three steps:

Formation of a database belonging to abiotic features: The geographical location of the research area, its contour lines, dominant peaks, numeric mapping layers belonging to geology, soil and hydrology features were brought together at ArcGIS and information on these features were put in Tables belonging to each layer, and thus databases were created.

Identification of actual land uses : Within the scope of the research, while deciding current land uses and their distribution in the research area, field observations, actual satellite images, $1 / 25000$ scale topographic maps, 1/25000 scale management plan and 1/5000 scale urban development plans were used. Utilizing these resources actual use types in the research area were identified. Using particularly field observation and satellite image information, vector-based map layers on actual land uses were obtained in ArcGIS.

Formation of biological database belonging to actual vegetation: In classifying the important biotopes to be protected, different abiotic features and land use varieties were considered as well as the diversity of plant cover. Vegetation collecting towards identifying the plant cover and inventory studies were carried out in a total of 156 releve areas which represent the areas with floristic and ecological diversity in rural and urban landscapes between the years 2006-2009.

Collection of specimens in forest and shrublands was carried out according to Braun-Blanquet (1964) method. During releve studies carried out in biotopes that have different habitats and variety of species, layer characteristics, existence and coverage degree of plant species were recorded in vegetation releve forms. Limit values of plant layers accepted by Scamoni (1963) were used in this study (Aksoy, 1978). Biological database created in MSACCESS programme and EXCEL data pages were used in preparing the list of plant species identified or recorded in the area. 


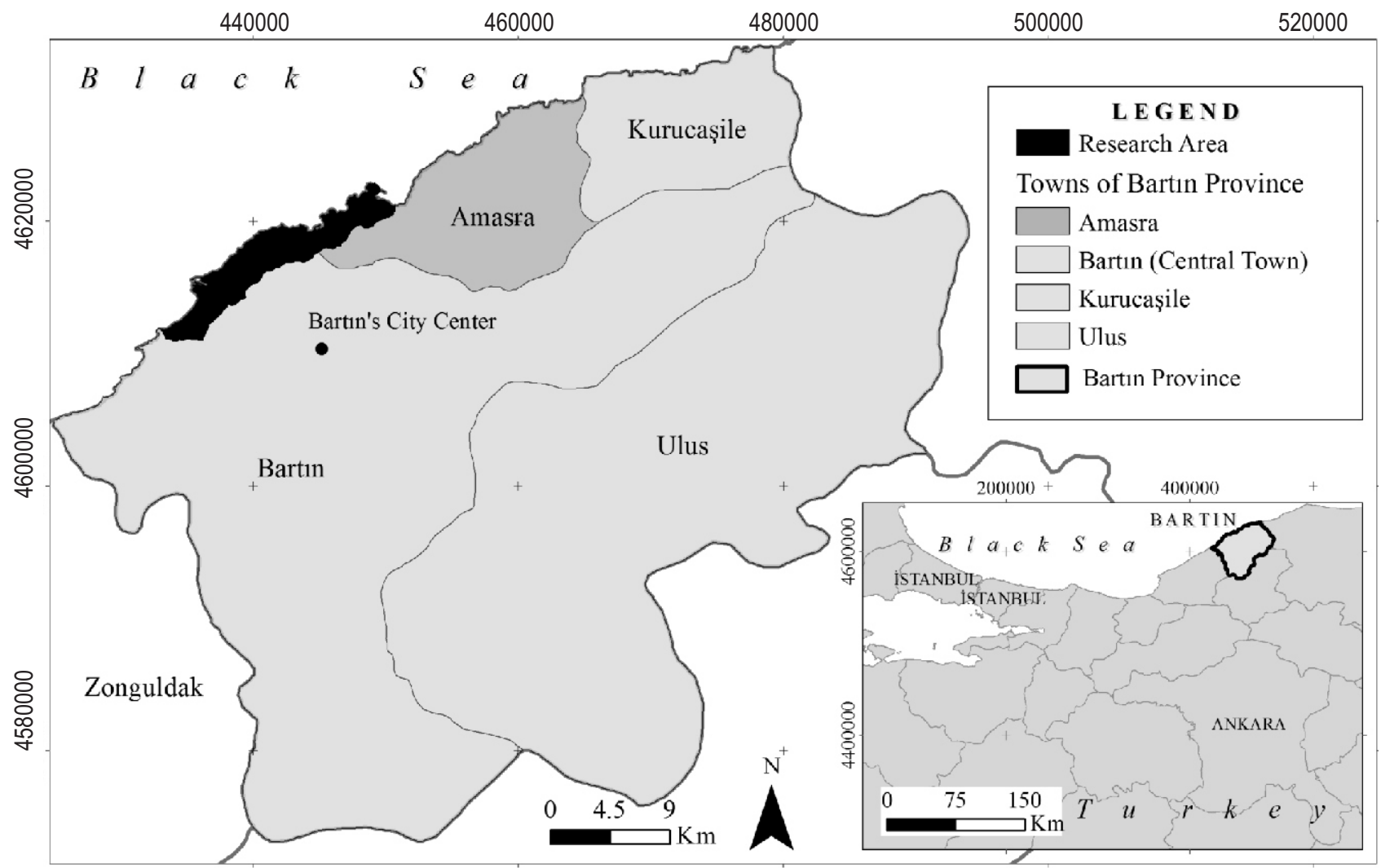

Fig. 1: Location of research area (Sarı Nayim and Ayaşlıgil, 2015)

In the study, flora and vegetation-based studies were given significant importance in order to reveal the plant species and compositions characterizing biotopes. Data on 92 vegetation collections in forest lands and shrublands were analyzed after they were organized as vegetation tables. Community-specific dominant and characteristic species were found. Using these tables it was possible to evaluate the relationship between abiotic features and communities. Pressure on the biotopes was also taken into consideration. In 64 sample areas, on the other hand, data on flora and vegetation, other abiotic features of the area and land use data were evaluated together.

Western Black Sea Region is an important biogeographical province in European continent (Atalay and Efe, 2015; 2010; Efe, 2010; European Commission, 2001). The area located within the borders of Bartın province, in the North of Turkey, covers the coastal mountains facing Black Sea and located between Amasra-Inkum settlements and the part of Bartın riverbed that connects to the sea. In addition, it is also located close to the buffer zone of Küre Mountains National Park, which is one of the 100 hot points in forest lands in Europe (Fig. 1).

The calycate-shaped area, which embodies most part of Bartın province, is divided as a valley on the north because of Bartın River and rests on a mountain chain. This mountain chain has a ridge line that starts on the east of İnkum and extends through northwest till Amasra. This chain of mountains, which is located on the north and west of Bartın province and within the scope of the research area, is formed of Upper Cretaceous and older rocks. A significant part of the research area is of old carbonate sediments. In addition, the Carboniferous carbonate sediments in the east of Tarlaağzı and the volcanic rocks that form the ridge line of the Amasra Mountains caused to the formation of distinct land shapes. Volcanic rocks are clearly seen at Kuşkaya Hill (Tüysüz et al., 2001; Sarı Nayim, 2010).

According to Zohary (1973) research area falls in Euxin Province part of Euro-Siberian Region, one of the three largest phytogeogrophical region covering Turkey. The climazone vegetation character of North Anatolia, where summers are humid, is a deciduous forest that is heterogeneous on the Black Sea coast and changes from mesophyll to hydrophilic and one that has rich species diversity (Mayer and Aksoy, 1998).

\section{Results and Discussion}

The research area whose altitude above sea level goes up to $489 \mathrm{~m}$ provides a typical sample of the mountain chains overlooking the Black Sea. Different characteristics of the natural structure of the area are: 
Cliffs close to the sea, low hills, dolines and calcareous lands with inclined slopes; Riverbed of Bartın River and Karasu Stream and alluvial plateaus; İnkum Dune areas and Rift valleys in Tarlaağzı, Gömü and Amasra settlements.

The characteristic plant cover of mountainous slopes overlooking Black Sea is of mixed deciduous forests of Euxin. On the other hand, in the parts close to the coast where the altitude is less, and in limestone areas and cliffs the competitive power of deciduous forests becomes reduced and they are replaced by pseudomaquis shrubs, partly due to human interference. It is not only field-specific natural values that differentiate the biotopes in the area but also cultural features (urban and rural settlements, agricultural areas, mines, afforestation, etc.).

Classification and mapping of the biotope types in the research area : The Main Biotope Types were classified under 11 topics after a general evaluation of actual vegetation structure, abiotic characteristics and actual land uses. These are deciduous forest lands, shrublands, cliffs, afforestation areas, agricultural lands, İnkum Dune area, Bartin Riverside, roadsides, destroyed areas, rural and urban settlement areas. These biotopes may be grouped in 30 sub-biotope types and a total of 41 biotope types were classified and mapped.

Deciduous forest lands: Deciduous forest lands were classified under 6 sub-biotopes according to the dominant species. With coverage rate ranging between 25-75\% Fagus orientalis, Carpinus betulus, Quercus spp., Ostrya carpinifolia; and with coverage rate ranging between $25-50 \%$ Castanea sativa and Tilia argentea were more dominant as compared to other species. With 108 species, Quercus community had the highest plant diversity followed by Fagus orientalis community which had 98 species and Castanea sativa community which had 95 species, Carpinus betulus community which had 92 species, Tilia argentea community which had 59 species and Ostrya carpinifolia community which had 21 species, respectively.

Forest communities dominated by Fagus orientalis: Fagus orientalis communities in the area extend on humid biotopes on volcanic sandstones, shales, limestone rocks having $10-45^{\circ}$ inclination at over 300-400 m altitude. However, they were also seen at $200 \mathrm{~m}$ altitude on slopes with medium and high inclination, in case these slopes were in valleys and straits protected from wind and severe weather conditions were rich in humidity. According to the biotope map, Fagus orientalis community covered $8 \%$ of the area. Castanea sativa and Carpinus betulus form the tree layer of the community, while Laurocerasus officinalis, Rhododendron ponticum s.str. and Ilex colchica joined the community in the shrub layer and Hedera colchica, Primula vulgaris ssp. sibthorpii and Trachystemon orientalis joined the herbaceous layer of the community.

Forest communities dominated by Castanea sativa: As in
North Anatolia, Castanea sativa, a sub-Mediterranean species, extends in a large area in choline coastal line in the study area. This community exists together with Beech communities and expands generally between 100-350 $\mathrm{m}$ in calcareous environments with sand and clay, which is open towards north and west and where the inclination is $10-45^{\circ}$. In Chestnut communities' tree layer, Carpinus betulus and Tilia argentea are generally seen, while Rhododendron ponticum s.str. and Cornus sanguinea ssp. australis join at the shrub layer and Hedera colchica, Trachystemon orientalis and Euphorbia amygdaloides s.str. join at the herbaceous layer.

Forest communities dominated by Carpinus betulus: In the choline layer in the study area and in the lower humid layers of mountainous parts, it is mostly deciduous tree species particularly lime, maple and oak trees and mixed stands that exist. Carpinus betulus communities, which occur on calcareous slopes between $100-200 \mathrm{~m}$ with $5-45^{\circ}$ inclination and with north and west exposure, leave their place to beech communities in the upper layers. They are especially found in humid straights, rift valleys overlooking north and stream sides. Carpinus betulus mostly groups with Tilia argentea, Acer campestre s.str. and Quercus cerris s.str. Ligustrum vulgare, Cornus mas and Cornus sanguinea ssp. australis are dominant species in the shrub layer and Helleborus orientalis, Hedera helix and Salvia forskahlei are dominant elements in the herbaceous layer.

Forest communities dominated by Quercus spp.: It is seen that three oak species stand out in the area. In dry lands under the impact of the sea it is Quercus pubescens and Quercus cerris s.str. forest communities that expand whilst in humid valleys and higher altitudes it is Quercus petraea ssp. iberica communities. Quercus roburs.str. joins the vegetation around riverbeds and on the sides of dry streams. Quercus infectoria s.str., on the other hand, is mostly found in communities where there are Quercus pubescens and Quercus cerris s.str. Homogenous low hills that allow northern winds and the southern and western slopes of humid valleys are the habitats of oak trees. Areas with calcareous limestone and shale and with $10-35^{\circ}$ inclination were the main features of the biotope.

Forest communities dominated by Tilia argentea: Lime trees individually join deciduous forests as communities within the area. However, protected humid slopes in İnum and Amasra where the temperature is optimum, they could be dominant. Biotope belonging to lime trees is the rocky slopes with limestone, sandstone and shale whose altitude ranged between 30-300 m and inclination was $10-45^{\circ}$. Tilia argentea, Carpinus betulus and Ostrya carpinifolia were found in the tree layer of the community, Euonymus latifolius ssp. cauconis and Cornus sanguinea ssp. australis were found in the shrub layer and Polystichum setiferum, Hedera helix and Orobanche hederae occured in the herbaceous layer of the community. 
Forest communities dominated by Ostrya carpinifolia: Ostrya carpinifolia generally prefers calcareous slopes with sand and lime and with $25-35^{\circ}$ inclination. It was found to thrive in calcareous low slopes at an altitude of 100-200 m at Amasra, Tarlaağzı village and it was replaced by beech trees and chestnut communities at higher altitudes. Ostrya carpinifolia generally formed community with Carpinus betulus and Castanea sativa. As in beech communities, the shrub layer of the community mostly included Laurocerasus officinalis, Rhododendron ponticum s.str. and Ilex colchica and in the herbaceous layer, it was Hedera colchica, Primula vulgaris ssp. sibthorpii and Viola odorata that stand out.

Shrublands: In dry and calcareous lands close to the coast where the deciduous Euxin forest communities lose their competitive power, shrubland biotopes were seen. Shrublands are mostly seen in dry limestone rocky areas and plane hills up to $200 \mathrm{~m}$ from the coast and with $10-50^{\circ}$ inclination. According to the biotope map, $6 \%$ of the area was covered with shrublands. Among the classified communities, shrublands represent the biotope with the highest number of species, which is 115 . It is found that there are also deciduous and semi-evergreen trees as Quercus pubescens, Q. cerris s.str., Q. infectoria s.str., Ostrya carpinifolia and Carpinus betulus as well as such everygreen shrubs as Laurus nobilis, Phillyrea latifolia, Myrtus communis s.str., Osyris alba, Arbutus unedo, Pistacia terebinthus s.str. and characteristic herbaceous species as Dorycnium pentaphyllum ssp. herbaceum, Anthemis tinctoria var. pallida and Scutellaria albida s.str. in the biotope.

Cliffs: Cliffs close to the sea are characteristic of the Black Sea coastal line. Difficulty in transportation resulted in less human impact on the biotope.

Deliklikaya, Demirli and Yılanlı Foreland extensions that limit the settlement in İnum, the cliffs around Bartın River and calcareous cliffs up to Tarlaağzı Bay represent rocky biotopes. The calcareous cliffs close to the coast in Amasra city center, Tarlaağzı and Gömü villages were included in this scope. This biotope, in which 98 plant species was found, includes the highest number of endemic and rare species. According to the biotope map, cliff biotopes covered $5 \%$ of the area. In this biotope which is rich in Mediterranean species, woody plants were mostly seen as shrubs or small trees. The small tree layer, which is dominated by Arbutus andrachne, Quercus pubescens, Ostrya carpinifolia and Pinus brutia, was supported by such shrubs as Phillyrea latifolia, Laurus nobilis and Arbutus unedo and such herbaceous plants as Centaurium erythraea s.str., Blackstonia perfoliata s.str., Clematis viticella and Galium album ssp. prusense.

Afforestation areas: Afforested areas were divided into :

Pinus pinaster afforestation areas; Pinus brutia afforestation areas; Pinus nigra ssp. pallasiana afforestation areas.

Pinus pinea afforestation areas: According to the biotope map afforestation areas extend in $27 \%$ of the area. It is found that the largest expansion was through the elimination of all natural vegetation in the hills and inclined slopes between Bartın Port and Tarlaağzı village. Fourteen percent of the biotope is Pinus brutia afforestations whilst $11 \%$ is Pinus pinaster afforestations; they are followed by Pinus nigra subsp. pallasiana afforestation areas and Pinus pinea and Cedrus libani afforestations in small areas.

Pinus pinaster afforestation areas: It was found that afforestation was carried out at fertile lands including limestone, shale, sandstone and coal rocks at $150-400$ m altitude and $10-45^{\circ}$ inclination that have north and west exposure. The implementation was carried out at areas where generally Fagus orientalis and Castanea sativa grow.

Pinus brutia afforestation areas: Calcareous cliffs with 5-35 inclination were preferred for afforestation. It was found out that Red Pine afforestation had been done by cutting out oak and hornbeam communities and pseudomaquis shrub biotopes located between elevation of 100-250 m.

Pinus nigra ssp. pallasiana afforestation areas: Pinus nigra ssp. pallasiana afforestation was carried out in calcareous slopes covered with Quercus spp. communities with $15-25^{\circ}$ inclination and generally overlooking south.

Pinus pinea afforestation areas: Afforestation was carried out in fertile valleys between Bartın Port and Tarlaağzı Port. It was found that the lower layer was covered with intense Rhododendron ponticum s.str.

Agricultural lands: According to the biotope map agricultural lands cover $16 \%$ of the area and they were made by opening areas in forests around the rural settlements.

Agricultural lands are divided into 5 sub-biotopes:

Croplands; Humid or semi-humid meadow areas; Dry and semi-dry grasslands; Hazelnut and Poplar plantation areas, and Tree communities and hedgerows on the agricultural land borders.

In Croplands, where a total number of 69 species were identified, it was mostly Heliotropium europaeum that was found. The areas where agricultural activities were most intensely carried out were Kapaklı town of Güzelcehisar, which is close to İnum settlement and Karasu Village. It was observed that agricultural activities based on Hazelnut and Strawberries, local products, were carried out in this area. Sunny cliffs under the sea effect were used as croplands and Hazelnut plantation areas. Hazelnut plantations were generally carried out inside or around forest lands where there was brown forest soil, which has 
sandstone-shale and has $11-20^{\circ}$ inclination. Poplar plantation areas and humid and semi-humid meadow areas spread along the mostly flat areas surrounding Bartın River and Karasu Stream and stream corridors connecting to low valleys.

Fertile lands on the skirts of the hills that restrict the river bed were generally used as croplands and Hazelnut plantation areas. Because agricultural lands were not used, dry and semidry grasslands were frequently seen around rural settlements and within forest lands. Due to deforestation in the area to build rural settlements and to carry out agricultural activities, existence of 20 tree communities of different sizes and hedgerows rich in species were identified.

İnkum Dune area: İnkum settlement on the slopes of cliffs has a 3 $\mathrm{km}$-long dune area. A total number of 45 plant species including dune and other herbaceous species were found in İnum Dune area. Among these species Pancratium maritimum is classified as 'Endangered' under high risk. Sand steps that are formed on dune areas with the impact of wind serve as a shelter for Pancratium maritimum and other dune species. There is an intense use on dune areas restricted with pedestrian and vehicle road especially during the summer months. The species forming the dune vegetation, which are under intense pressure, face the danger of extinction and there are no measures taken towards protecting these species.

Bartın Riverside : The deep valley of Bartın River divides the study area into two. The valley is limited with hills of dolomitic limestone whose height ranges between 130-230 m. Irrigated agricultural lands and Poplar and Hazelnut tree plantations are seen in large part of the alluvial planes around the river. Due to wind, the tree height comes down to 4-5 $\mathrm{m}$ at the entrance of the strait and they are replaced with shrublands. However, as one moves towards the inner parts, the tree height increases, and shrublands are replaced with deciduous mixed forests. Lime trees on the limestone slopes restricting the river valley join Quercus spp. communities in sunny slopes and Carpinus betulus communities in shady areas. Areas dominated by Carpinus betulus in the lower parts are replaced with Fagus orientalis in the upper parts. On the other hand, the riverside vegetation on the river corridor, where Salix alba is dominant, forms a green corridor system together with Fraxinus angustifolia and Alnus glutinosa. There are reeds covered with Phragmites australis on sides close to the river mouth.

Roadsides: Plant species on road sides differ according to where they grow in mountainous lands or in plane alluvial lands. Humid ditches on roadsides are important as they allow different species to grow. Roadsides that pass through the forest and shrubland biotopes in Amasra and İnkum includes many tree, shrub and herbaceous taxa belonging to these biotopes as well as ruderal species. Herbaceous plants, such as, Echium angustifolium, Echium vulgare, Euphorbia sequieriana s.str., Anthemis tinctoria ssp. pallida, Dorycnium pentaphyllum ssp. herbaceum, Inula viscosa, Pallenis spinosa and Conyza canadensis could be counted among the roadside-specific species. Roadsides that go through slopes covered with such forest vegetation including Fagus orientalis, Carpinus betulus, Ostrya carpinifolia and Quercus cerris s.str. caused to the existence of delicate roadside biotopes due to the species they host.

Degraded areas: Degraded areas are divided into four subbiotopes, namely,

Mines; Solid and liquid waste landfill area Port land; Riverside degraded areas.

Mines: Coal mining in Amasra, Tarlaağzı and Gömü to collect coal, stone and clay has destroyed forest lands dominated by Quercus spp. and Carpinus betulus and also extensively changed the land structure.

Solid and liquid waste landfill area: An old coal mine at Yılanlı Foreland, located between Bartın Port and İnkum, is used as a solid waste landfill area. Liquid waste, on the other hand, is discharged at a place in Yılanlı Foreland where there are cliffs and shrublands, which include endemic species.

Port land: During the construction of Bartın Port, the natural morphological structure of the river mouth was damaged. Due to the stone barriers built at the side of riverbed to prevent floods, the shore vegetation has become sparse or has totally disappeared.

Riverside degraded areas: After the flood in Bartın province, some studies have been carried out around the river bed. Within the scope of these studies, the flow direction of the river at the point where the river empties into the Black Sea was changed and sand filled areas were created. Artificial sand areas by the side of the river caused many foreign herbaceous species, which were totally different from the natural vegetation in the coast, to invade these areas. Amaranthus retroflexus, Heliotropium dolosum, Chenopodium album s.str. and Anthemis cotula are among the species found in these areas.

Urban settlements: While determining the urban biotopes of Amasra and İnkum settlements, urban land uses and differences in plant cover were taken into consideration. In addition to woody and herbaceous ornamental plants that different biotope areas cover, natural herbaceous and woody taxa that adjusted to urban settlements were found. Quercus cerris s.str. and Laurus nobilis were natural woody species identified in the urban area. Besides, 85 of the exotic taxa identified in urban areas were woody plants whilst 14 were herbaceous. Urban biotopes were classified under 11 sub-biotopes which are intense residential areas, private and public gardens, calcareous cliffs and historical castle walls, unused empty areas, urban agricultural areas, parks and squares, cemeteries, roadside green areas, Bedesten historic area, Military lands and Boztepe Peninsula and Tavşan Island dry 
grasslands.

Rural settlements : The rural settlements from west to east were Kapaklı, Karasu, Esenpınar, Tarlaağzı and Gömü. All the rural settlements except Kapaklı district were on the fertile areas of morphologically rift valleys. Most of the villages were located at slopes at lower inclinations between $0-20^{\circ}$, hill planes or fertile lands close to water. Since the villages were located in the forest lands, there were species belonging to the natural vegetation in the villages. Especially, village cemeteries bear the traces of potential vegetation before the settlement in the area. Quercus petraea ssp. iberica and Carpinus betulus semi-natural forest remnant found in Kapaklı district village cemetery is an example of this case. Also, it is possible to see such rare species as Scilla bithynica and Viola canina in the joints of the stone walls of garden borders

\section{Factors that negatively affect biotopes}

During the field surveys, it was identified that there had been important changes in the biotopes around Bartın Port and particularly in Amasra and İnkum urban settlements. The factors that negatively affect rural and urban biotopes are listed below:

The expansion of settlements; Existence of mine and stone quarries; Enterprises of constructing a thermal power plant (Amasra-Tarlaağzı); Ports; Destruction of forest areas for agricultural activities; Existence of waste landfill areas; Increase in demand for tourism and recreational activities (Particularly expansion of settlement based on second house, and intense use of dune areas); Illegal cutting of forest lands; Improvement work around Bartın River; Tunnel connection, road construction and expansion works around Amasra.

Eleven main biotopes were identified. These biotopes were divided into 30 sub-biotopes. Furthermore, 620 plant taxa were identified within semi-natural and cultural biotopes. Overall, 521 natural taxa and 99 cultivated taxa were determined from the urban and rural landscape areas. The taxa identified in the study area can be summarized as; 13 endemic species, 44 species including 7 endangered species according to IUCN Red List, 12 taxa which are not included in the Red List but are still rare species along with 28 geophytes stated in Ekim et al. (2000) which should be conserved with their biotopes (Sarı Nayim, 2010; Sarı Nayim and Ayaşlıgil, 2015).

Euonymus latifolius ssp. cauconis and Lamium purpureum var. aznavourii, endemic taxa identified in the biotopes are on the list of endangered species on global scale (Ekim et al., 2000; Özhatay et al., 2005). Seseli resinosum is a local endemic taxon growing in Zonguldak, Bartın-Amasra and Kastamonu and Western Black Sea Region. The other endemic species were Asyneuma limoniifolium ssp. pestalozzae, Tragopogon aureus, Knautia degenii, Crocus ancyrensis, Ballota nigra ssp. anatolica, Sideritis dichotoma, Stachys cretica ssp. anatolica, Bupleurum setaceum, Heracleum platytaenium and Ferulago plathycarpa (Sarı Nayim, 2010; Sarı Nayim and Ayaşlıgil, 2015).

The natural biotopes and species existing in the study area were compared with EUNIS Habitat Classifications prepared within the International Habitat Types, and species to be protected as noted in Natura 2000 Habitat Directives Appendix II as well as Natura 2000 Habitat lists created specifically for Black Sea biogeographical region (European Commission, 2003; EUNIS, 2005; EIONET, 2008). Biotopes compatible with the lists are specified below:

Coastal and Halophytic Habitats,

Vegetated sea cliffs of the Mediterranean Coasts

Vegetated cliffs and rock shores of the Mediterranean, of the Mediterraneo-temperate eastern Atlantic (South-western Iberia) and of the Black Sea.

Coastal Sand dunes and inland dunes

Fixed coastal dunes with herbaceus vegetation

Temperate heath and scrub,

Mediterranean arborescent matorral

Rocky habitats and caves

Calcareous rocky slopes with chosmophytic vegetation Forests

Forests of temperate Europe

Oak-hornbeam forests

Euro-Siberian steppic woods with Quercus spp.

Pannonian woods with Quercus pubescens

Western Pontic Beech forests

Atlantic and Medio-European Oak or Oak-Hornbeam forests of Carpinus betulus

Tilio-Acerion forests of slopes, screes and ravines

Alluvial forests with Alnus glutinosa and Fraxinus excelsior

Riparian mixed forests of Quercus robur, Ulmus laevis, U. minor, Fraxinus excelsior, F. angustifolia, along the great rivers.

Mediterranean deciduous forests

Castanea sativa woods

Salix alba and Populus alba

On the other hand, the human beings and nature have been involved in a continuous interaction in the study area, which has a 3000-year old historical and cultural background. In the region, which includes Amasra and İnkum tourism centers, Bartın Port, Military Port as well as 5 rural settlements, traditional utilization has caused significant changes in the natural environment.

When the negative factors identified in the biotopes were taken into consideration, a planning understanding is needed for the study area, which was close to the buffer zone of the Küre Mountains National Park which is an important conservation area on both national and international scale; embraces important 
cultural and touristic city centers like Amasra and İnkum; offers sensitive species and habitat diversity at the same time.

Ensuring the continuity of biotopes and species against various land uses and their protection and development requires periodically monitored legal management at regional and local level.

Suggestions for conservation and improvement of the biotopes at the landscape scale : The history of the area, cultural structure as well as the view value produced by the coastsea relationship necessitate the management of the landscape by preserving. As it is known, landscape consists of a body of ecosystems, continuously in interaction with each other. Considered within this scope, it will not be enough to save biotopes and species only in the boundaries of the research area in the adjacent zone of the National Park buffer zone.

Therefore; A 'Protected Landscape / Seascape, aiming the conservation, management and improvement of the biotopes within the study area and all the terrestrial, freshwater and maritime ecosystems that can affect them should be created; Protected area should be managed, focusing on nature conservation and recreation. The main objectives of the management are; Ensuring the continuity and diversity of species and biotopes by applying nature conservation to all forms of area utilization. Supporting nature tourism which draws worldwide interest in the sustainable regional development.

Bartın - Amasra - İnkum (BAi) Protected Landscape has been suggested within the scope of 'Protected Landscape/ Seascape', the 5. type of the 6 area management categories of IUCN, according to Dudley (2008), as well as the 'Protected Landscape/Seascape' of the protected area types in Germany. Both of them are protected area types in which preservation precautions are not strictly practiced and which give importance to the preservation of historical and cultural values as well as the natural flora and fauna and recreation. In the management of the landscape, the management aims and criteria, practiced in such protected areas, should be adopted.

It is possible to see several implementations in which important protected areas in Europe as well as recreation and tourism are linked together for the application of the NATURA 2000 Habitat Directives which aim to preserve the important species and biotopes (BfN, 2010). The implementation abroad compatible with 'BAI Protected Landscape's natural and cultural characteristic should be taken as example. How the balance is realized between protection aims and recreation needs necessary for biotopes and species, especially in the planning and management phase, should be particularly focused on. Carrying capacity works should move in during this phase.

Conservation of all natural biotopes and species in the study area, which show similarity with International Habitat
Classifications, will contribute to biological diversity and nature conservation not only in our country but also on a global scale. With the mapping of the biotopes covering species that have a special importance in the area, a base has been achieved to manage the formation of aims and conservation status of the ecosystems special to the Black Sea at landscape level.

\section{Acknowledgements}

This article summarizes the studies implemented to determine the biotopes for the Ph.D. thesis titled as 'The Mapping of the Important Biotopes Located between Amasra-İnkum (Bartın)' and supervised by Prof. Dr. Yahya Ayaşlıgil. This work was supported by the Zonguldak Karaelmas University Scientific Research Projects Commission Directorate in the scope of number 2007/2-59-02-10 research project.

\section{References}

Aksoy, H.: Studies on the Silvicultural Practices in the KarabükBüyükdüz Forest Research Area. Istanbul University, Faculty of Forestry Publ.No.2332, 237, Istanbul (1978).

Atalay, İ. and R. Efe: Biogeography of Turkey (Türkiye Biyocoğrafyası). Meta Press, Izmir, Turkey (2015).

Atalay, I. and R. Efe: Ecological attributes and distribution of Anatolian Black Pine [Pinus nigra Arnold. subsp. pallasiana Lamb. Holmboe)] in Turkey. J. Environ. Biol., 33, 509-519 (2012).

Atalay, I. and R. Efe: Structural and distributional evaluation of forest ecosystems in Turkey. J. Environ. Biol., 31, 61-70 (2010).

Ayaşlıgil, Y.: Biotope mapping and the importance of landscape planning. Urban and Ecology Symposium on Nature Conservation, İstanbul Technical University \& Nature Conservation Foundation of Turkey, December 18-19, 199-208, İstanbul (1997).

Ayaşıgil, Y. and F. Duhme: Prospects of Köprülü Kanyon National Park for meeting both conservation targets and people's need for development. Landsc. Urban Plan., 24, 143-151 (1993).

Ayaşlıgil, Y.: Der Köprülü Kanyon Nationalpark-Seine Vegetation und ihre Beeinflussung durch den Menschen. Landschaftsökologie Weihenstephan. Heft 5, 307, Tab. U. Karten, Zsfg. en, fr, dt, Freising (1987).

Bastian, O. and U. Steınhardt: Development and perspectives of Landscape Ecology. Kluwer Academic Publishers, Netherlands, 1 4020-0919-4 (2002).

BfN: Natura 2000 and outdoor recreation and tourism-A guideline for the application of The Habitats Directive and The Birds Directive. Federal Agency for Nature Conservation, Germany, http://www. dosb.de/fileadmin/fm-dosb/arbeitsfelder/umweltsportstaetten/ Veroeffentlichungen/Natura2000_English_web.pdf(2010).

Braun-Blanquet, J.: Pflanzensoziologie. Wien-New York (1964).

Chytry, M., T. Kucera and M. Koci: Habitat catalogue of the Czech Rebublic, interpretation manual for the European programmes Natura 2000 and Emerald (in Czech). Agency for Nature Conservation and Landscape Protection of the Czech Republic, Praha (2001)

Cousins, S.A.O. and M. Ihse: A methodological study for biotope and landscape mapping based on CIR aerial photographs. Landsc. Urban Plan., 41, 183-192 (1998).

Curebal, I., R. Efe, A. Soykan and S. Sönmez: Impact of anthropogenic 
factors on land degradation during Anthropocene in Turkey. $J$. Environ. Biol., 36, 51-58 (2015).

Dahl, F.: Grundsaetze und grundbegriffe der biocoenotischen forshung. Zool. Anz., 33, 349-353 (1908).

Davies, C.E., D. Moss and M.O. Hill: EUNIS habitat classification revised 2004. EEA-European Topic Centre on Nature Protection and Biodiversity (2004).

Devillers, P., J. Devillers-Terschuren and J.P. Ledant: CORINE biotopes manual, habitats of the European community. Vol.3, ECSC-EECEAEC, Brussels (1991).

Dudley, N.: Guidelines for applying protected area management categories. IUCN, Switzerland, http://www.unep-wcmc.org/ protected_areas/categories/index.html (2008).

Efe, R.: Biogeography (Biyocoğrafya), MKM Publ, Bursa, Turkey (2010).

EIONET: Blacksea Region Reference List, Natura 2000 Habitat Directive Annex I-II. ETC/BD,France,http://biodiversity.eionet.europa.eu/ activities/Natura_2000/pdfs/Ref_bla.pdf(2008).

Ekim, T., M. Koyuncu, M. Vural, H. Duman, Z. Aytaç and N. Adıgüzel: Red Data Book of Turkish Plants (Pteridophyta and Spermatophyta). Turkish Association for the Conservation of Nature, Ankara, 97593611-0-8 (2000).

Environmental Atlas: Berlin Digital Environmental Atlas/Biotope Types. Berlin Senate Department for Urban Development, Berlin, http://www.stadtentwicklung.berlin.de/umwelt/umweltatlas (2009).

EUNIS: European Nature Information System. http://eunis.eea.eu. int/index.jsp (2005).

European Communities: Habitats of the European Community Corine Biotopes manual. Volume 2, Commission of the European Communities L-2920, Luxemburg, 92-826-3211-3 http://biodiversity-chm.eea. europa .eu/ information/ document [May, 21 2007] (1991).

European Commission: The Biogeographical regions, Europe 2001. European EnvironmentAgency http://dataservice.eea. europa.eu/ atlas [February, $9^{\text {th }}$ 2006] (2001).

European Commission: Interpretation manual of European Union habitats. EUR25, European Commission, Brussels (2003).

European Commission: Natura 2000 in the Black Sea Region. European Commission, Luxembourg, ISBN 978-92-79-11585-1, 12p,www.ec.europa.eu/environment/nature (2009).

Farina, A.: Principles and methods in landscape ecology. Kluwer Academic Publishers, Netherlands, 0412730405 (2000).

Forman, R.T.T.: Land Mosaics. Cambridge University Press, Cambridge (1995).

Forman, R.T.T and M. Godron: Landscape Ecology. John Wiley, New York (1986).

Guth, J. and T. Kucera: Natura 2000 habitat mapping in the Czech Republic: methods and general results. Ekologia, 24, Bratislava (2005).

Hersperger, A.M.: Landscape ecology and its potential application to planning. J. Plan. Lit., 9, 14-29 (1994)

Jarvis, P.J. and C.H. Young: The mapping of urban habitat and its evaluation. A discussion paper prepared for the Urban Forum of the United Kingdom Man and the Biosphere Programme http://www.ukmaburbanforum.co.uk/Downloadable\%20Pubs/MA Bpaper.pdf(2005)

JNCC: Terrestrial Habitats. UK Habitat Classification. Joint Nature Conservation Council, UK, www.jncc.defra.gov.uk (2014).

Löfvenhaft, K., C. Björn and M. Ihse: Biotope patterns in urban areas: a conceptual model integrating biodiversity issues in spatial planning. Landsc. Urban Plan., 58, 223-240 (2002).

Mayer, H. and H. Aksoy: Turkey Forests. Ministry of Forestry, Forestry Research Institute of the Western Black Sea, Publ. No.1, Bolu, (1998).

Ministry of Environment and Forestry: The National biological diversity strategy and action plan. DKMP Headquarters, Republic of Turkey, General Directorate of Nature conservation and national parks, department of nature conservation, Ankara (2007).

Ministry of Environment and Forestry: Official website adress [July, $1^{\text {st }}$ 2010](2010)

Münier, B., B. Nygaard, R. Ejrnaes and H.G. Bruun, A biotope landscape model for prediction of semi-natural vegetation in Denmark. Ecol. Model., 139, 221-233 (2001).

Odum, E.P. and G.W. Barrett: Fundamentals of Ecology. Brooks/Cole, Thomson learning, USA(2005)

Oudheusden, R.: The Corine Biotopes Project. Department of Science, Technology and Society, Utrecht University (2005).

Özhatay, N., A. Byfield, and S. Atay: 122 Important plant areas of Turkey WWF, Istanbul, Turkey (2005).

Sarı Nayim, Y.: Mapping of the Important Biotopes Located between Amasra-Inkum (Bartın) (in Turkish). Ph.D. thesis, Istanbul University, Graduate School of Natural and Applied Sciences, Istanbul (2010).

Sarı Nayim, Y. and Y. Ayaşlıgil: Contributions to the flora between Amasra and İnkum (Bartın) located in Western Black Sea Region. Biol. Divers. Conserv., 8/3, Eskişehir, Turkey (2015).

Scamoni, A.: Einführung in die praktische vegetationskunde, Jena (1963).

Sukoop, H. and S. Weiler: Biotope mapping and nature conservation strategies in urban areas of the Federal Republic of Germany. Landsc. Urban Plan., 15, 39-58 (1988).

Tüysüz, O., Ş.C. Genç and U. Tarı: Geological and morphological features of Bartın and surrounding area. ITÜ Eurasia Institute of Earth Sciences Technical Report, 2000/11/003, İstanbul (2001).

Werner, P.: Urban biotope mapping-The use of data and maps for urban management and planning-Experiences from Germany. Institute for Housing and Environment, Darmstadt, Germany (2006).

Yılmaz, H.: Mapping of the biotopes in the town of Bartın and its surrounding area. Ph.D. thesis, Istanbul Univ. Graduate School of Natural and Applied Sciences, Istanbul (2001).

Zerbe, S., U. Maurer, S. Schmitz, and H. Sukopp: Biodiversity in Berlin and its potential for nature conservation. Landsc. Urban Plan., 62, 139-148 (2003).

Zohary, M.: Geobotanical foundations of the Middle East. Gustav Fischer Verlag, Stuttgart(1973) 